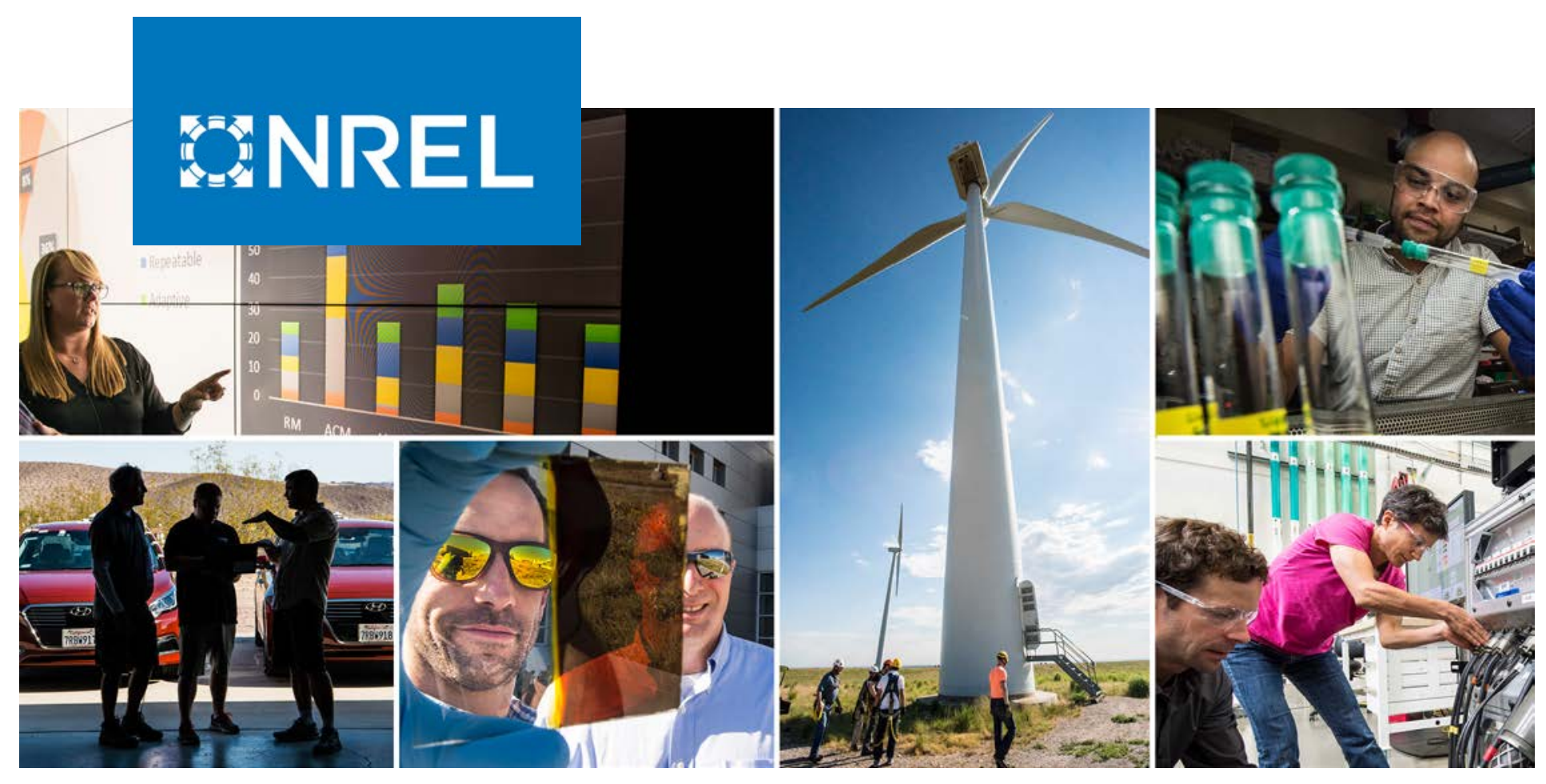

\title{
Continuous Improvement Workshops: Stakeholder Ideas for Improving the Weatherization Assistance Program
}

Juliana Williams

National Renewable Energy Laboratory

NREL is a national laboratory of the U.S. Department of Energy Office of Energy Efficiency \& Renewable Energy

Operated by the Alliance for Sustainable Energy, LLC

This report is available at no cost from the National Renewable Energy Laboratory (NREL) at www.nrel.gov/publications.
Technical Report

NREL/TP-6A20-75594

January 2020 


\title{
GNREL
}

\section{Continuous Improvement Workshops: Stakeholder Ideas for Improving the Weatherization Assistance Program}

\author{
Juliana Williams
}

National Renewable Energy Laboratory

\section{Suggested Citation}

Williams, Juliana. 2020. Continuous Improvement Workshops: Stakeholder Ideas for Improving the Weatherization Assistance Program. Golden, CO: National Renewable Energy Laboratory. NREL/TP-6A20-75594. https://www.nrel.gov/docs/fy20osti/75594.pdf.

NREL is a national laboratory of the U.S. Department of Energy Office of Energy Efficiency \& Renewable Energy Operated by the Alliance for Sustainable Energy, LLC

This report is available at no cost from the National Renewable Energy Laboratory (NREL) at www.nrel.gov/publications.

Contract No. DE-AC36-08GO28308
Technical Report NREL/TP-6A20-75594 January 2020

National Renewable Energy Laboratory 15013 Denver West Parkway Golden, CO 80401 303-275-3000 • www.nrel.gov 


\section{NOTICE}

This work was authored by the National Renewable Energy Laboratory, operated by Alliance for Sustainable Energy, LLC, for the U.S. Department of Energy (DOE) under Contract No. DE-AC36-08GO28308. Funding provided by U.S. Department of Energy Office of Energy Efficiency and Renewable Energy Weatherization and Intergovernmental Programs Office. The views expressed herein do not necessarily represent the views of the DOE or the U.S. Government.

This report is available at no cost from the National Renewable Energy Laboratory (NREL) at www.nrel.gov/publications.

U.S. Department of Energy (DOE) reports produced after 1991 and a growing number of pre-1991 documents are available free via www.OSTI.gov.

Cover Photos by Dennis Schroeder: (clockwise, left to right) NREL 51934, NREL 45897, NREL 42160, NREL 45891, NREL 48097, NREL 46526.

NREL prints on paper that contains recycled content. 


\section{Acknowledgments}

The work described in this document was funded by the U.S. Department of Energy's (DOE) Weatherization Assistance Program (WAP) under the Guidelines for Home Energy Professionals project. The author would like to thank the WAP professionals who volunteered their time to participate in the Continuous Improvement Workshops, as well as Advanced Energy and Simonson Management Services for their support in workshop design and facilitation. 


\section{List of Acronyms}

AMI

DOE

CAP

$\mathrm{H} \& \mathrm{~S}$

NASCSP

NCCER

NREL

QA

QCI

SWS

T\&TA

WAP

WIOA

WPN
Area Median Income

Department of Energy

Community Action Partnership

Health and Safety

National Association for State Community Service Programs

National Center for Construction Education \& Research

National Renewable Energy Laboratory

Quality Assurance

Quality Control Inspector

Standard Work Specifications

Training and Technical Assistance

Weatherization Assistance Program

Workforce Innovation and Opportunity Act

Weatherization Program Notice 


\section{Table of Contents}

1 Background .......................................................................................................................................

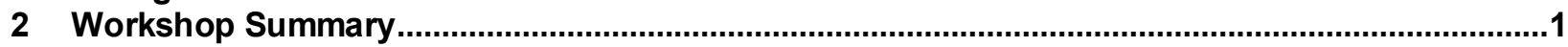

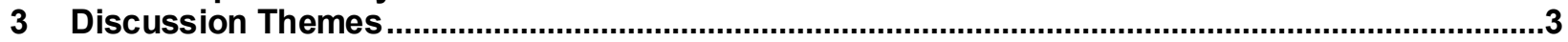

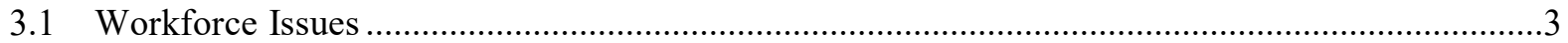

3.2 Guidance from DOE Project Officers........................................................................

3.3 Sharing of Best/Good Practices ........................................................................................4

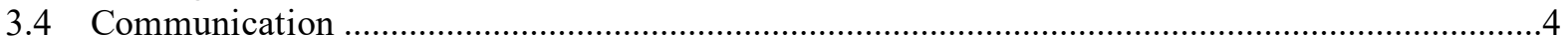

4 Root Cause Barriers and Potential Actions ............................................................................4

5 Synthesis of Potential DOE Actions Brainstormed by Participants ..............................................9

6 Lessons Learned from Continuous Improvement Workshops................................................. 11 


\section{List of Figures}

Figure 1. Location and Stakeholder Type of Workshop Participants.........................................................2

Figure 2. Degree of impact and complexity of potential DOE actions brainstormed by participants .........10

\section{List of Tables}

Table 1. Continuous Improvement Workshop Participation ...................................................................2

Table 2. Barriers to Grantee Performance and Potential Actions ................................................................

Table 3. Barriers to Subgrantee Performance and Potential Actions ............................................................... 


\section{Background}

The U.S. Department of Energy (DOE) Weatherization Assistance Program (WAP or program) reduces energy costs for low-income households by increasing the efficiency of their homes, while ensuring their health and safety. The program supports 8,500 jobs and provides weatherization services to approximately 35,000 homes every year using DOE funds. Through weatherization improvements and upgrades, these households save, on average, \$283 or more every year, according to a national evaluation of the program. Since the program began in 1976, the WAP has helped improve the lives of more than 7 million families through weatherization services. WAP is implemented by a network of 57 Grantees and over 700 Subgrantees, who administer the program at the local level. The program is also supported by accredited training centers and other WAP stakeholder organizations.

Given the broad network of implementers within the program, DOE sought to engage with WAP stakeholders to solicit feedback and gain a deeper understanding of on-the-ground operations. Through a series of Continuous Improvement Workshops in 2019, network stakeholders identified opportunities for improved coordination, training, procedures, and communication across all levels of the WAP. These workshops built on a previous cycle of Solution Summits held in 2017. Actionable ideas generated through the Continuous Improvement Workshops were synthesized by the National Renewable Energy Laboratory (NREL) and are presented in this report for DOE's consideration.

\section{Workshop Summary}

Three Continuous Improvement Workshops were held in 2019 and brought together 52 stakeholders from around the country. The workshops were held in coordination with the following conferences to minimize travel requirements for participants: the 2019 National Home Performance Conference and Trade Show; the Community Action Partnership (CAP) 2019 Annual Convention; and the National Association for State Community Services Programs (NASCSP) 2019 Annual Training Conference. The first workshop was facilitated by Advanced Energy, and the second and third were facilitated by NREL.

Participants were recruited through an application process announced in January 2019. Applicants were selected for one of three workshops based on availability, experience, organizational diversity, and geographic diversity. Participation for each workshop is summarized in Table 1. 
Table 1. Continuous Improvement Workshop Participation

\begin{tabular}{llll}
\hline & $\begin{array}{l}\text { Chicago, IL } \\
\text { April 4-5, 2019 }\end{array}$ & $\begin{array}{l}\text { Chicago, IL } \\
\text { August 27, 2019 }\end{array}$ & $\begin{array}{l}\text { Little Rock, AR } \\
\text { September 27, 2019 }\end{array}$ \\
\hline Grantee & 4 & 3 & 11 \\
\hline Subgrantee & 7 & 8 & 3 \\
\hline Training Center & 3 & - & 2 \\
WAP Stakeholder & 4 & 5 & 2 \\
\hline Total & 18 & 16 & 18
\end{tabular}

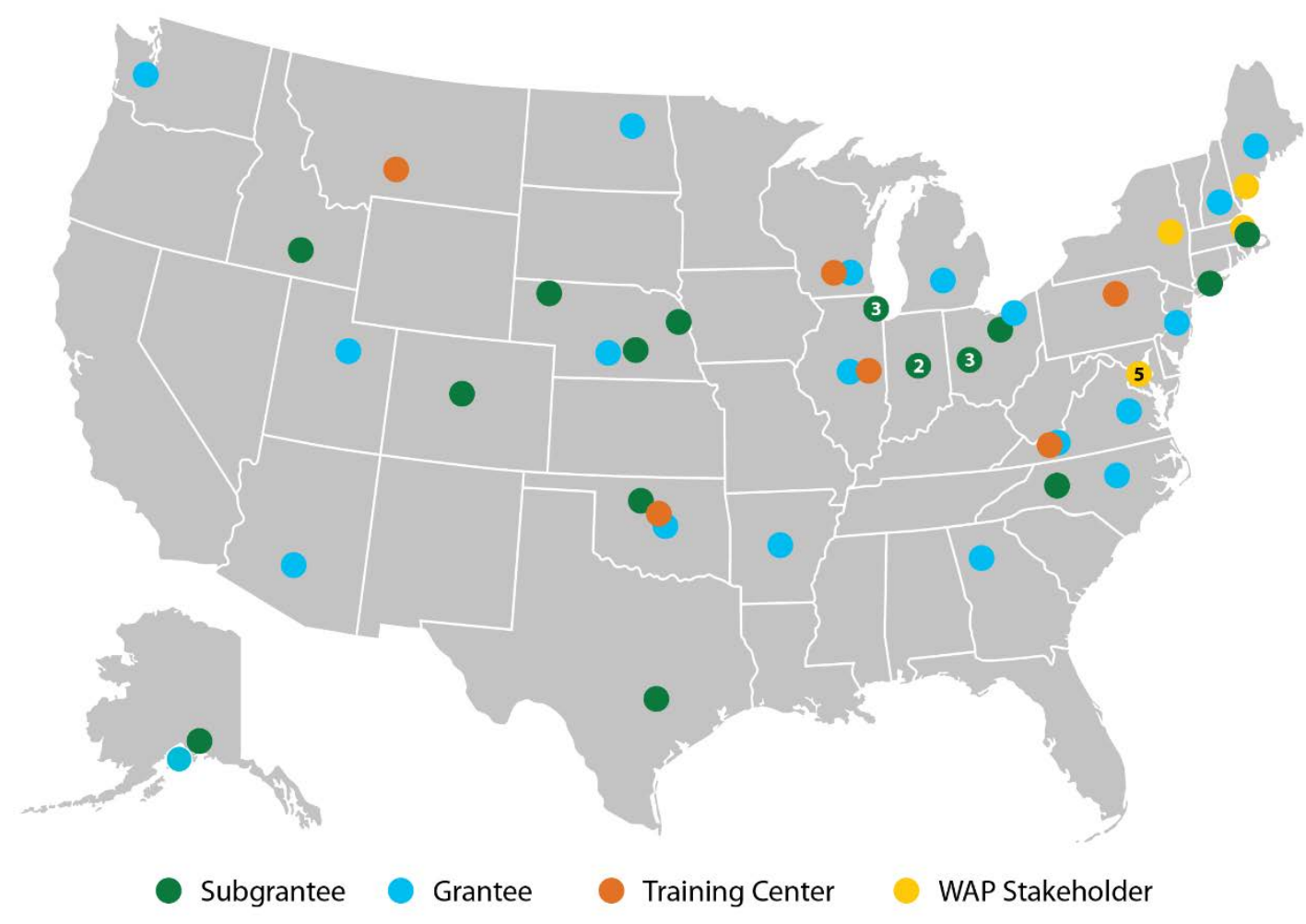

Figure 1. Location and Stakeholder Type of Workshop Participants

The workshops were organized around three objectives:

1. Define elements of baseline performance and high performance within the $\mathrm{WAP}^{1}$

2. Identify the root cause barriers to achieving baseline performance

3. Brainstorm actions at all levels of the WAP that address the root cause barriers.

\footnotetext{
${ }^{1}$ The first workshop used the term "compliant performance." NREL believed this term skewed the focus of the first workshop toward Subgrantee compliance and switched to "baseline performance" for the other workshops.
} 
For the purpose of these workshops, baseline performance was defined as: "WAP stakeholders perform at a level that complies with statutes and regulations and supports the provision of appropriate services to eligible households." High performance was defined as: "WAP stakeholders perform at level that complies with statutes and regulations, maximizes provision of appropriate services to eligible households, and adeptly responds to internal and external challenges." Distinguishing between the characteristics of baseline and high-performing programs allowed participants to focus on barriers to baseline performance throughout in the workshops.

Participants used a "5 Whys" approach to identify root cause barriers preventing baseline performance across the WAP. This iterative technique identifies cause-and-effect relationships of a given outcome. By repeating the question "Why?" multiple times, the answers progressively lead to more systemic causes. Several elements of performance were found to have multiple root cause barriers. After prioritizing barriers that would be most useful to address, participants used a Continuous Improvement template to facilitate brainstorming of potential actions that could be taken across all levels of the WAP to address the barriers to baseline performance.

\section{Discussion Themes}

Across the three workshops, several recurring themes emerged regarding the root cause barriers brainstormed by participants. Although these themes are addressed to an extent through the potential actions presented in Section 4, further exploration of potential actions is worth DOE consideration.

\subsection{Workforce Issues}

In the second workshop, each small group independently identified workforce development and retention root cause barriers. Although some of the groups brainstormed partial solutions to workforce issues, participants recognized that this issue was broader than the workshop participants, and even DOE, could fully address. Recruitment to trades, including building science and home performance, has not kept up with demand in the broader economy. With a relatively robust economy and demand for similar skills in the private sector, Subgrantees, and to some extent Grantees, have found it difficult to attract and retain enough qualified staff in both rural and urban areas. Workforce development and retention also came up at the third workshop, but participants decided to focus their efforts on other topics that they could more directly affect. Although this report does not contain many specific recommended actions for DOE to address workforce issues, we encourage DOE to explore longer-term efforts to expand the weatherization and building science workforce.

\subsection{Guidance from DOE Project Officers}

In each workshop, the facilitators reserved time after the identification of root cause barriers to identify resources and efforts already underway that address the perceived barriers. During this discussion, it became apparent that not all participants were aware of the existing DOE resources available. Grantee participants also identified that they were not always aware of the degree of flexibility available to them within the program structure. Grantees voiced concern that guidance or expectations from DOE Project Officers were not always consistent or readily available. The recent reorganization to Programmatic Project Officers and Technical Project Officers may 
address this Grantee desire for more access, better understanding of existing flexibility, and consistent interpretation.

\subsection{Sharing of Best/Good Practices}

Subgrantee and Grantee participants at all workshops expressed difficulty leveraging best practices from their peers to avoid needing to reinvent the wheel. Reasons identified included: other higher priorities occupying staff time; inability to identify appropriate peers; lack of understanding which practices are best/good practices; and lack of appropriate forums to connect and share such practices. Subgrantees may not always know what approaches Grantees view favorably. This may be due to insufficient communication from a Grantee, lack of peer sharing among Subgrantees, turnover among Subgrantee or Grantee staff, or other reasons. Similarly, Grantees may not always know what approaches DOE views favorably. Reluctance to label practices as "best" is understandable, given fluctuating levels of performance and continued evolution of the program. However, there are options available to DOE to facilitate the sharing of "good," if not "best," practices among Grantees, some of which are listed below.

\subsection{Communication}

Participants at all levels identified the need for more effective communication between levels of the WAP. Subgrantees expressed desire for Grantee communications via multiple media (websites, emails, webinars, etc.) with adequate lead times for participation or implementation. Grantees expressed desire for greater Subgrantee participation in update cycles for various components of annual Grantee Plans or other policy documents. Grantees identified need for more media and platforms for peer-to-peer communication, as well as additional opportunities for informal communication with DOE. Given the layered structure of the WAP, communication within and between WAP levels is paramount for effective and compliant implementation. The participants in the workshops brainstormed many ideas to improve communication within the WAP, but there are likely additional opportunities for improvement. NREL recommends that DOE continue to explore opportunities to improve communication with Grantees and support Grantees in improving communication with their Subgrantees.

\section{Root Cause Barriers and Potential Actions}

The barriers to performance brainstormed by participants largely addressed challenges faced by Grantees and Subgrantees. Potential actions to address these barriers involved action at all levels of the WAP and were shaped by participants' degree of visibility into other WAP levels. Tables 2 and 3 below present the root cause barriers identified by participants that the WAP network has control to influence, as well as associated actions likely to address each barrier. 
Table 2. Barriers to Grantee Performance and Potential Actions

\begin{tabular}{|c|c|c|c|c|}
\hline Barrier to Performance & Potential DOE Actions & $\begin{array}{l}\text { Potential } \\
\text { Grantee Actions }\end{array}$ & $\begin{array}{l}\text { Potential } \\
\text { Subgrantee Actions }\end{array}$ & Potential WAP Stakeholder Actions \\
\hline $\begin{array}{l}\text { Grantee Operations Manual is } \\
\text { not comprehensive or multiple } \\
\text { documents do not align due to } \\
\text { lack of clarity on what constitutes } \\
\text { a comprehensive Operations } \\
\text { Manual; lack of Grantee process } \\
\text { for developing or maintaining } \\
\text { Operations Manual }\end{array}$ & $\begin{array}{l}\text { Identify common elements } \\
\text { that may be included in a } \\
\text { comprehensive Operations } \\
\text { Manual, similar to Standard Work } \\
\text { Specifications (SWS) } \\
\text { Provide recommendations to } \\
\text { Grantee during monitoring activities } \\
\text { on how program documents, } \\
\text { including Operations Manual, can } \\
\text { be improved } \\
\text { Continue providing short webinars } \\
\text { on policy changes }\end{array}$ & $\begin{array}{l}\text { House all program documents in } \\
\text { one easily accessible place } \\
\text { Provide Subgrantees sufficient } \\
\text { time to provide input on Operations } \\
\text { Manual changes (ask Subgrantees } \\
\text { how much time is sufficient) } \\
\text { Engage Subgrantee network in } \\
\text { policy changes beyond email } \\
\text { announcements } \\
\text { Establish and communicate clear } \\
\text { process for updating Operations } \\
\text { Manual }\end{array}$ & $\begin{array}{l}\text { Provide input to Grantee on } \\
\text { consistency of Operations Manual } \\
\text { and on proposed changes }\end{array}$ & $\begin{array}{l}\text { NASCSP: provide more } \\
\text { communication of DOE changes } \\
\text { in newly issued Weatherization } \\
\text { Program Notices (WPNs) compared } \\
\text { to prior guidance } \\
\text { Training Centers: better inform } \\
\text { network of opportunity for } \\
\text { customized trainings, such as on } \\
\text { maintaining Operations Manual }\end{array}$ \\
\hline $\begin{array}{l}\text { Inability to implement nationally } \\
\text { standardized administrative } \\
\text { systems and processes at the } \\
\text { Grantee level due to regional and } \\
\text { state-specific circumstances }\end{array}$ & $\begin{array}{l}\text { Provide platform for sharing } \\
\text { common elements of Grantee } \\
\text { plans, Operations Manuals, etc., } \\
\text { similar to SWS. Enable "upvoting" } \\
\text { to help network identify good (if not } \\
\text { best) practices }\end{array}$ & $\begin{array}{l}\text { Post Grantee plan and policy } \\
\text { documents online for other } \\
\text { Grantees to view }\end{array}$ & N/A & $\begin{array}{l}\text { NASCSP: Make Grantee plan and } \\
\text { policy documents available online } \\
\text { to other Grantees } \\
\text { CAP: Create portal for Subgrantee } \\
\text { policy documents } \\
\text { Other: Establish a Grantee hub for } \\
\text { management issues, similar to the } \\
\text { Trainer's Consortium }\end{array}$ \\
\hline $\begin{array}{l}\text { Inadequate Grantee staff capacity } \\
\text { due to small staffs; reluctance of } \\
\text { Grantees to hire more staff at the } \\
\text { expense of production }\end{array}$ & $\begin{array}{l}\text { Engage in discussion with Grantees } \\
\text { regarding the balance between } \\
\text { Grantee staffing to manage } \\
\text { program versus total number units } \\
\text { weatherized } \\
\text { Consider approval of Grantee plan } \\
\text { components (field guide, energy } \\
\text { audit tools, etc.) in different } \\
\text { cycles, as appropriate, to support } \\
\text { Grantees with smaller staffs }\end{array}$ & $\begin{array}{l}\text { Leverage Subgrantee expertise } \\
\text { to support maintenance of policy } \\
\text { documents }\end{array}$ & $\begin{array}{l}\text { Engage in Grantee plan and policy } \\
\text { update process, offering expertise } \\
\text { as appropriate }\end{array}$ & $\begin{array}{l}\text { Establish peer-to-peer exchange } \\
\text { forum searchable by subject/topic/ } \\
\text { issue }\end{array}$ \\
\hline
\end{tabular}


Table 2. Barriers to Grantee Performance and Potential Actions

\begin{tabular}{|c|c|c|c|c|}
\hline Barrier to Performance & Potential DOE Actions & $\begin{array}{l}\text { Potential } \\
\text { Grantee Actions }\end{array}$ & $\begin{array}{l}\text { Potential } \\
\text { Subgrantee Actions }\end{array}$ & Potential WAP Stakeholder Actions \\
\hline $\begin{array}{l}\text { Grantee difficulty implementing } \\
\text { policy changes due to confusion } \\
\text { about effective dates; DOE not } \\
\text { publishing all policy documents } \\
\text { prior to or at the start of the } \\
\text { Program Year; lack of clarity of DOE } \\
\text { timeline for approval of Grantee } \\
\text { plans }\end{array}$ & $\begin{array}{l}\text { Establish clear distinctions } \\
\text { between "effective date" and } \\
\text { "publish/issue date" for WPNs, } \\
\text { and make clearly visible at top } \\
\text { Build out PAGE database to include } \\
\text { audit letters, variances, etc., and } \\
\text { to provide the status of Grantee } \\
\text { submissions (example: under } \\
\text { review, approved) } \\
\text { Ensure consideration of Grantee } \\
\text { implementation timelines in review } \\
\text { of policy changes }\end{array}$ & $\begin{array}{l}\text { Attend webinar hosted by DOE, } \\
\text { NASCSP regionals calls } \\
\text { Provide comments to DOE on draft } \\
\text { changes before final issuance }\end{array}$ & $\mathrm{N} / \mathrm{A}$ & N/A \\
\hline $\begin{array}{l}\text { Limited ability of Grantees to learn } \\
\text { from each other and leverage } \\
\text { each other's resources due to } \\
\text { inadequate forums for exchange }\end{array}$ & $\begin{array}{l}\text { Encourage/support other regions } \\
\text { to organize similar to Energy } \\
\text { OutWest } \\
\text { Provide funding for "big tent" online } \\
\text { peer-to-peer exchange platform }\end{array}$ & $\begin{array}{l}\text { Participate in developing agendas } \\
\text { for NASCSP regional calls }\end{array}$ & $\mathrm{N} / \mathrm{A}$ & $\begin{array}{l}\text { Establish platform for sharing } \\
\text { elements of Grantee plans } \\
\text { and policy documents. Enable } \\
\text { "upvoting" for network to identify } \\
\text { good practices } \\
\text { Build database of Grantee } \\
\text { characteristics to identify peers to } \\
\text { engage for support. Characteristics } \\
\text { could include: \% single family } \\
\text { v. multifamily, \# of staff, \# of } \\
\text { Subgrantees, urban/rural split, } \\
\text { allowance of solar, leveraged funds, } \\
\text { productions levels } \\
\text { Create forums for technical staff to } \\
\text { engage and discuss updates and } \\
\text { implementation issues } \\
\text { Allow for more time for self- } \\
\text { directed/ organic Grantee } \\
\text { discussion of crowdsourced topics } \\
\text { at conference }\end{array}$ \\
\hline
\end{tabular}


Table 3. Barriers to Subgrantee Performance and Potential Actions

\begin{tabular}{|c|c|c|c|c|}
\hline Barrier to Performance & Potential DOE Actions & $\begin{array}{l}\text { Potential } \\
\text { Grantee Actions }\end{array}$ & $\begin{array}{l}\text { Potential } \\
\text { Subgrantee Actions }\end{array}$ & Potential WAP Stakeholder Actions \\
\hline $\begin{array}{l}\text { Client complaints inadequately } \\
\text { addressed by Subgrantee due to } \\
\text { lack of formal complaint resolution } \\
\text { process; lack of clear expectations }\end{array}$ & $\begin{array}{l}\text { During review of Grantee plan, ask } \\
\text { Grantee: } \\
\text { Are Subgrantees required to have a } \\
\text { complaint resolution process? } \\
\text { Has Grantee provided a sample } \\
\text { policy on complaint resolution? } \\
\text { Has Grantee made training } \\
\text { available on complaint resolution? }\end{array}$ & $\begin{array}{l}\text { Establish clear parameters on } \\
\text { expectations for Subgrantee } \\
\text { complaint resolution process } \\
\text { Provide sample/template } \\
\text { complaint resolution procedure to } \\
\text { Subgrantees } \\
\text { Make training available to } \\
\text { Subgrantees on complaint } \\
\text { resolution process }{ }^{2}\end{array}$ & $\begin{array}{l}\text { Establish clear complaint } \\
\text { resolution process } \\
\text { Complaint resolution process, } \\
\text { including points of contact, are } \\
\text { available on Subgrantee website } \\
\text { Implement internal training } \\
\text { Build culture of customer service }\end{array}$ & N/A \\
\hline $\begin{array}{l}\text { Subgrantee misses production } \\
\text { goals due to lack of training in } \\
\text { forecasting accurate production } \\
\text { numbers; lack of fiscal } \\
\text { management training }\end{array}$ & $\begin{array}{l}\text { Develop training on fiscal } \\
\text { management and production } \\
\text { forecasting } \\
\text { Provide monthly production tracking } \\
\text { template for Grantees to use and } \\
\text { send to Subgrantees } \\
\text { During Grantee Plan review and } \\
\text { monitoring, ask Grantee how it } \\
\text { communicated training resources } \\
\text { to Subgrantees }\end{array}$ & $\begin{array}{l}\text { Develop state production tracking } \\
\text { system } \\
\text { Send out regular dashboard/ } \\
\text { spreadsheet of Subgrantee } \\
\text { production to allow Subgrantees } \\
\text { to facilitate peer exchange among } \\
\text { Subgrantees } \\
\text { Serve as matchmaker for peer } \\
\text { exchange between Subgrantees on } \\
\text { meeting production goals }\end{array}$ & $\begin{array}{l}\text { Participate in training on fiscal } \\
\text { management and production } \\
\text { forecasting } \\
\text { Engage in peer exchange with other } \\
\text { Subgrantees } \\
\text { Integrate fiscal and production } \\
\text { forecasting training into succession } \\
\text { planning }\end{array}$ & $\begin{array}{l}\text { Dedicate a track at conferences for } \\
\text { fiscal management }\end{array}$ \\
\hline $\begin{array}{l}\text { Inadequate maintenance of } \\
\text { energy audit tools due to lack of } \\
\text { training on update process; lack of } \\
\text { feedback on accuracy of audit tool } \\
\text { inputs }\end{array}$ & $\begin{array}{l}\text { Ask Grantees about their review } \\
\text { of Subgrantee audit tool measure } \\
\text { libraries and inputs as part of QA } \\
\text { process }\end{array}$ & $\begin{array}{l}\text { Create feedback mechanism to } \\
\text { review measure lists and inputs } \\
\text { (especially fuel prices) } \\
\text { Develop fuel prices inputs for } \\
\text { Subgrantees or institute QA } \\
\text { protocols } \\
\text { Review audit tool measure libraries } \\
\text { and inputs as part of QA } \\
\text { Participate in training on audit } \\
\text { tools }\end{array}$ & $\begin{array}{l}\text { Participate in training on audit } \\
\text { tools and inputs }\end{array}$ & $\begin{array}{l}\text { Training Centers develop training } \\
\text { for: } \\
\text { Managers and supervisors on audit } \\
\text { tools and how to review them } \\
\text { Energy auditors on modifying } \\
\text { inputs } \\
\text { Crew supervisors to recognize } \\
\text { when audit tool recommendations } \\
\text { do not align with expectations }\end{array}$ \\
\hline
\end{tabular}

${ }^{2}$ Development of online training module on client engagement is under development.

2everopment. 
Table 3. Barriers to Subgrantee Performance and Potential Actions

\begin{tabular}{|c|c|c|c|c|}
\hline Barrier to Performance & Potential DOE Actions & $\begin{array}{l}\text { Potential } \\
\text { Grantee Actions }\end{array}$ & $\begin{array}{l}\text { Potential } \\
\text { Subgrantee Actions }\end{array}$ & Potential WAP Stakeholder Actions \\
\hline $\begin{array}{l}\text { Lack of qualified staff due to } \\
\text { insufficient entry-level recruitment }\end{array}$ & $\begin{array}{l}\text { Explore partnerships with } \\
\text { YouthBuild, Americorps, the } \\
\text { National Center for Construction } \\
\text { Education \& Research (NCCER), } \\
\text { and leverage Workforce Innovation } \\
\text { and Opportunity Act (WIOA) } \\
\text { resources to recruit entry-level staff } \\
\text { Explore allowing Training and } \\
\text { Technical Assistance (T\&TA) funds } \\
\text { to be used for apprenticeship } \\
\text { programs }\end{array}$ & $\begin{array}{l}\text { Partner with utilities to provide } \\
\text { stipends for training } \\
\text { Review Subgrantee training plans } \\
\text { for inclusion of professional } \\
\text { development outside of } \\
\text { certifications, in alignment with } \\
\text { WPN 15-4 } \\
\text { Explore flexibility in providing T\&TA } \\
\text { funds to Subgrantees }\end{array}$ & $\begin{array}{l}\text { Conduct recruitment and outreach } \\
\text { activities including, but not limited } \\
\text { to: trade school partnerships; } \\
\text { high school career days; diverse } \\
\text { backgrounds } \\
\text { Communicate opportunities for } \\
\text { retraining of individuals making a } \\
\text { career change } \\
\text { Communicate career pathways } \\
\text { to employees through Job Task } \\
\text { Analyses (JTAs) and internal } \\
\text { advancement opportunities }\end{array}$ & $\begin{array}{l}\text { Training Centers: Better } \\
\text { communicate that trainings are } \\
\text { available to individuals who are not } \\
\text { already Subgrantee employees }\end{array}$ \\
\hline $\begin{array}{l}\text { Lack of Quality Control Inspectors } \\
\text { (QCIs) due to inadequate retention } \\
\text { of highly trained staff }\end{array}$ & $\begin{array}{l}\text { Develop national salary scale for } \\
\text { standard positions based on area } \\
\text { median income (AMI) } \\
\text { Consider a waiver process to allow } \\
\text { Grantees to allow Subgrantee to } \\
\text { continue production for a period if } \\
\text { insufficient QCIs are available and } \\
\text { require the Grantee to increase QA } \\
\text { monitoring during that period }\end{array}$ & $\begin{array}{l}\text { Partner with utilities to provide } \\
\text { stipends for training } \\
\text { Explore flexibility in providing T\&TA } \\
\text { funds to Subgrantees }\end{array}$ & $\begin{array}{l}\text { Partner with utilities to provide } \\
\text { stipends for training } \\
\text { Partner with nearby Subgrantees to } \\
\text { share QCls }\end{array}$ & N/A \\
\hline $\begin{array}{l}\text { High percentage of deferrals due to } \\
\text { lack of consistency in the deferral } \\
\text { process; Subgrantee/contractor } \\
\text { bandwidth or ability to perform } \\
\text { necessary repairs }\end{array}$ & $\begin{array}{l}\text { Define what constitutes a deferral, } \\
\text { including subcategories for } \\
\text { tracking, such as deferrals due to: } \\
\text { health and safety (H\&S), structural } \\
\text { issues of the home, client or } \\
\text { unit eligibility, referred to another } \\
\text { program }\end{array}$ & $\begin{array}{l}\text { Request data on deferral rates, } \\
\text { including subcategories of } \\
\text { deferrals }\end{array}$ & $\begin{array}{l}\text { Track deferral rates, including } \\
\text { subcategories of deferrals }\end{array}$ & N/A \\
\hline
\end{tabular}




\section{Synthesis of Potential DOE Actions Brainstormed by Participants}

Due to resource and other constraints it may be difficult for DOE to implement all the potential actions simultaneously. Some of the brainstormed actions are complex, require partnerships beyond DOE, or have lengthy implementation timelines, thus limiting DOE capability in implementation. Figure 2 organizes the potential DOE actions by expected level of impact and expected level of complexity of implementation. This is intended to assist DOE in prioritizing actions for implementation on near-, mid- and long-term timeframes.

The potential actions that involve the development of online resources, external partnerships, or significant policy changes are considered to have a high degree of complexity, whereas those action that involve adjustments to existing DOE processes or additional engagement with Grantees are considered to have a low degree of complexity. In general, the time frame for implementation is expected to increase with higher complexity, so the complexity axis in Figure 2 can be used as a proxy for implementation timelines.

The potential actions considered to have higher levels of impact are those that introduce broad changes to the program, are likely to significantly address a barrier to performance, or involve development of online tools or resources. Potential actions considered to have lower levels of impact may have limited applicability to the whole WAP network, only partially address a barrier to performance, or impact a relatively narrow barrier to performance.

The organization of the potential actions along these two axes is intended to assist in understanding and should not be interpreted to reflect the relative merits of any potential action over another. DOE may find it valuable to implement actions considered to have low impact in the near term while planning for actions with higher complexity. The list of potential actions brainstormed by workshop participants should not be considered comprehensive, and hopefully this list of actions generates additional ideas for improvement. 


\section{Impact}

-Distiguish between "effective date" and "published date" in WPNs

-Provide recommenations to Grantee on Operations Manual improvements

-Engage with Grantees on balance between staffing and production

-Provide monthly production tracking template to Grantees to provide to Subgrantees

-Identify common elements in a comprehensive Operations Manual -Continue webinars on policy change -Consider Grantee implementation timeline in policy change rollout

-Ask Grantee about review of

Subgrantee complaint resolution

-Ask Grantee about review of Subgrantee audittool inputs

-Establish definition of "deferral" including subcategories for tracking
-Provide platform for sharing common elements of Grantee documents, similar to SWS

-Provide funding for "big tent" online peer-to-peer exchange

-Build out PAGE database to include Grantee documents and status

-Develop fiscal management and production forecasting training (already in development)

-Explore partnerships with YouthBuild/Americorps/WIOA

\section{Complexity}

-Consider approval of Grantee plan components on different cycles

-Support other regions to organize similar to Energy OutWest

-Explore allowing use of T\&TA funds

for apprenticeship programs

-Develop national payscale for

standard positions by AMI

-Consider waiver process to allow

production if insufficient QCls

available, with additonal monitoring

Figure 2. Degree of impact and complexity of potential DOE actions brainstormed by participants. Actions related to Grantee barriers to performance in black, actions relation to Subgrantee barriers in white. 


\section{Lessons Learned from Continuous Improvement Workshops}

Participants reported that the Continuous Improvement Workshops were a valuable conduit of ideas from across the network to DOE. Post-workshop evaluation responses were received from 22 of the 52 participants. Participants valued the diversity of perspectives within each workshop and felt it contributed to the depth of understanding around barriers, existing resources, and ideas for improvement. In general, participants agreed that the workshops focused on the right outcomes and were effective in meeting those outcomes. In survey responses, several participants indicated that they intend to use the 5 Whys problem-solving approach with their organizations. All but one survey respondent indicated that they would be very likely to recommend that other members of the WAP network participate in future workshops.

Several potential improvements were identified in the evaluations. The workshops were oriented around addressing the barriers to baseline performance, with the aim of lifting all WAP stakeholders to meet WAP expectations and requirements; however, the decision to focus on baseline performance was not decided until after participants were selected to attend. A few participants expressed frustration that the workshops focused on barriers to baseline performance rather than barriers to high performance (as defined above), because they felt that baseline performance had been discussed at length before. There was also some frustration that the structure of the workshop was not communicated far enough in advance or lacked focus. To address the frustration, NREL intends to set the topics for future workshop agendas prior to the application process. For the 2020 cycle, DOE may want to consider focusing on barriers to high performance, which may have spillover benefits for baseline performance. While NREL did not attempt to assign stakeholders to a baseline or high-performance state, the elements of performance brainstormed by workshop participants could be developed into self-assessment tools for WAP stakeholders.

Beyond focusing on barriers to high performance, participants provided the following suggestions for improving the agenda for future workshops:

- hold separate tracks or workshops on administrative and technical elements of the program;

- delve into the metrics of performance used by DOE;

- address workforce development more deeply; and

- conduct a survey of applicants prior to the workshop to tailor topics to the attendees.

Several participants expressed a desire for more DOE participation in the workshops to offer context and hear directly from participants.

Finally, while the participants brainstormed actions that could be taken at all levels of the WAP network, DOE faces a challenge in communicating these ideas to Grantees, Subgrantees, Training Centers, and other WAP stakeholders. For the 2020 Continuous Improvement Workshops, participants articulated a wish for DOE and NREL to expand work with stakeholders in advance of the workshops to identify ways to engage the full WAP network in the resulting ideas for improvement. 